\title{
Antifouling character of 'active' hybrid xerogel coatings with sequestered catalysts for the activation of hydrogen peroxide
}

\author{
Danielle M. McMaster ${ }^{\mathrm{a}}$, Stephanie M. Bennett ${ }^{\mathrm{a}}$, Ying Tang ${ }^{\mathrm{a}}$, John A. Finlay ${ }^{\mathrm{b}}$, Gregory L. Kowalke ${ }^{\mathrm{c}}$, \\ Brian Nedved ${ }^{\mathrm{d}}$, Frank V. Bright ${ }^{\mathrm{a}}$, Maureen E. Callow ${ }^{\mathrm{b}}$, James A. Callow ${ }^{\mathrm{b}}$, Dean E. Wendt ${ }^{\mathrm{c}}$, \\ Michael G. Hadfield ${ }^{\mathrm{d}}$ and Michael R. Detty ${ }^{\mathrm{a} *}$ \\ ${ }^{a}$ Department of Chemistry, University at Buffalo, The State University of New York, Buffalo, New York, USA; ${ }^{b}$ School of \\ Biosciences, The University of Birmingham, Edgbaston, Birmingham, UK; ${ }^{c}$ Biological Sciences Department, California Polytechnic \\ State University, California, USA; ${ }^{d}$ Kewalo Marine Laboratory, University of Hawaii at Manoa, Honolulu, Hawaii, USA
}

\begin{abstract}
Halide-permeable xerogel films prepared from sols containing $50 \mathrm{~mol} \%$ aminopropyltriethoxysilane (APTES) $/ 50$ mol\% tetraethoxysilane (TEOS) or $10 \mathrm{~mol} \%$ APTES $/ 90 \mathrm{~mol} \%$ TEOS and $0.015 \mathrm{M}$ selenoxide or telluride catalyst in the sol gave reduced settlement of cypris larvae of the barnacle Balanus amphitrite and larvae of the tubeworm Hydroides elegans in the presence of artificial seawater (ASW) and hydrogen peroxide $(5-100 \mu \mathrm{M})$ relative to glass controls. Settlement of Ulva zoospores was lower on both the $50 \mathrm{~mol} \%$ APTES $/ 50 \mathrm{~mol} \%$ TEOS and $10 \mathrm{~mol} \%$ APTES $/ 90 \mathrm{~mol} \%$ TEOS xerogel formulations in comparison with glass controls with or without the added catalyst. The $50 \mathrm{~mol} \%$ APTES $/ 50 \mathrm{~mol} \%$ TEOS xerogel containing telluride catalyst gave reduced settlement of Ulva zoospores in the presence of $100 \mu \mathrm{M} \mathrm{H}_{2} \mathrm{O}_{2}$ in ASW compared with the same coating without added peroxide. Scanning electron microscopy and XPS data suggest that exposure to $\mathrm{H}_{2} \mathrm{O}_{2}$ does not lead to chemical or morphological changes on the xerogel surface.
\end{abstract}

Keywords: active xerogels; hydrogen peroxide; biofouling; algae; Ulva; barnacles; Balanus amphitrite; tubeworms; Hydroides elegans

\section{Introduction}

Worldwide, marine biofouling is a significant economic problem costing $\$ 30-\$ 60$ million per year in transportation costs due to increased fuel consumption from added drag (Townsin 2003; Schultz 2007). The most common method to minimise biofouling is to coat the submerged surface with an antifouling (AF) paint that leaches biocide(s) to prevent marine life from attaching to the surface (Yebra et al. 2004). A number of alternative technologies are available commercially, the most notable being based on silicone elastomers, which release accumulated fouling under suitable hydrodynamic conditions (eg Kavanagh et al. 2005; Wendt et al. 2006).

A conditioning film forms within seconds of immersion and is followed by settlement of bacteria, unicellular algae and cyanobacteria (blue-green algae) to form a biofilm within hours of immersion. Surfaces bearing this biofilm rapidly become overgrown by macrofoulers such as barnacles, tubeworms and macroalgae (Callow 2000).

The barnacle Balanus amphitrite is a common member of fouling communities in coastal environments (Clare and Høeg 2008) and it is often found in great abundance on ships' hulls and pier pilings and it has an extremely wide geographical distribution (Otani et al. 2007). The polychaete tubeworm Hydroides elegans is a common member of the hard-fouling community in tropical and sub-tropical waters and is an early colonist of submerged surfaces in Pearl Harbour (Pettengill et al. 2007). Ulva (syn. Enteromorpha) (Hayden et al. 2003) is a key macroalga that fouls ships and is tolerant of a wide range of environmental conditions and surface coating types including biocidal AF paints (Callow 1996). Dispersal of Ulva is mainly through motile, quadriflagellate zoospores, which are released in large numbers and which respond to a large number of settlement cues (Callow and Callow 2000). The settlement (attachment) of these three organisms was used to evaluate the xerogel surfaces in the present study.

An alternative to the use of biocides in the marine environment to minimise biofouling is to design a surface whose characteristics discourage either biofilm formation or the settlement of fouling organisms or whose characteristics reduce the strength of attachment of fouling organisms such that they are more easily removed by hydrodynamic forces (Callow et al. 2000; 2002; Finlay et al. 2002; Genzer and Efimenko 2006). Hybrid xerogel coatings with critical surface 
energies near $20 \mathrm{mN} \mathrm{m}^{-1}$, which is in the range where minimal bioadhesion is observed due to the formation of weak boundary layers (Baier et al. 1968; Baier 1984), reduce the settlement of cyprids of the barnacle $B$. amphitrite and, for one xerogel coating, display excellent fouling-release properties for juvenile barnacles (Tang et al. 2005).

Another approach to reduce fouling is to use naturally occurring reagents in seawater to create biocides in situ. Halide salts are slowly oxidised by $\mathrm{H}_{2} \mathrm{O}_{2}$ to give positive halogen species, which are known to have biocidal properties (Williams and Schroeder 2004). In the open ocean, concentrations of $\mathrm{H}_{2} \mathrm{O}_{2}$ approach 0.2 $\mu \mathrm{M}$ and can be much higher (up to $50 \mu \mathrm{M}$ ) in coastal areas where concentrations in rain water and runoff are in the range of 16-526 $\mu \mathrm{M}$ (Cooper and Zika 1983; Willey et al. 1999; Yuan and Schiller 2000, 2001; Clark et al. 2008). At these peroxide concentrations and in the presence of the $0.5 \mathrm{M}$ chloride, $1 \mathrm{mM}$ bromide and 1 $\mu \mathrm{M}$ iodide found in seawater, the production of positive halogen species cannot overcome the rate at which the positive halogen species decompose or are consumed.

$\mathrm{H}_{2} \mathrm{O}_{2}$ is also formed on submerged surfaces by organisms in the biofilm (Chandrasekaran and Dexter 1993; Le Bozec et al. 2001; Dexter et al. 2003). Local concentrations of $\mathrm{H}_{2} \mathrm{O}_{2}$ in the biofilm can approach $50 \mu \mathrm{M}$.

Diorganoselenoxides and diorganotellurides are efficient catalysts for the oxidation of halide salts with $\mathrm{H}_{2} \mathrm{O}_{2}$ to produce the corresponding hypohalous acid (Francavilla et al. 2000, 2001; Higgs et al. 2001; Drake et al. 2003; Goodman and Detty 2004; Bennett et al. 2008). If these catalysts were covalently sequestered within a porous film coating, the catalysts should react with the peroxide found in seawater (Cooper and Zika 1983; Willey et al. 1999; Yuan and Schiller 2000, 2001; Clark et al. 2008) or that is produced by the biofilm (Chandrasekaran and Dexter 1993; Le Bozec et al. 2001; Dexter et al. 2003) and with the halide salts found in seawater to create a surface that is chemically inhospitable to settlement and adhesion. Specifically, the catalysts would generate hypohalous acid or 'bleach' on the coating surface. The biocide(s) could inhibit settlement by either killing or deterring the attachment of larvae or spores, but if they settle the constant generation of hypohalous biocides, might be expected to kill or inhibit the growth of the attached organisms.

Xerogel films prepared by the sol-gel process are easily processed near ambient conditions, are economically and environmentally friendly, and can be applied to surfaces by a variety of means including spraying, brushing or rolling, dip coating and spin coating. In addition, the properties of the xerogel including porosity, permeability towards various ions and neutral molecules, and the extent of crosslinking can be controlled by the precursors one uses and the processing conditions (Brinker and Scherer 1990; Avnir 1995; Dave et al. 1995; Ingersoll and Bright 1997; Jordan et al. 1998). Furthermore, other reagents can be sequestered within the xerogel and these reagents can maintain their normal chemical reactivity/function found in solution (Avnir 1995; Dave et al. 1995; Pandey et al. 2000; Tang et al. 2003).

This investigation examines the performance of two-component, hybrid xerogel films that are doped with 4-(hydroxymethyl)phenyl benzyl selenoxide (Se1) or 3-(n-hexyltelluro)- 1-propanol (Te1) (Chart 1) as 'active' coatings to minimise the biofouling. Specifically, settlement and growth of fouling species can be minimised by the generation of hypohalous acids from the $\mathrm{H}_{2} \mathrm{O}_{2}$ and halide salts naturally occurring in seawater. The xerogel films were formed from sols that are composed of $50 \mathrm{~mol} \%$ aminopropyltriethoxysilane (APTES) and $50 \mathrm{~mol} \%$ tetraethoxysilane (TEOS) or $10 \mathrm{~mol} \%$ APTES and $90 \mathrm{~mol} \%$ TEOS. These active coatings have been examined with respect to the settlement of cyprids (cypris larvae) of $B$. amphitrite, larvae of $H$. elegans, and Ulva zoospores. Glass was included as an inert standard.

\section{Materials and methods}

\section{Chemical reagents}

All reagents were used as received. Deionised water was prepared to a specific resistivity of at least 18 $\mathrm{M} \Omega$ using a Barnstead NANOpure II system. TEOS, tetramethoxysilane (TMOS), 3-propyltrimethoxysilane (C3TMOS) and 3-aminopropyltriethoxysilane were obtained from Gelest. Hydrochloric acid was obtained from Fisher Scientific. Ethanol was a product of Quantum Chemical. Borosilicate glass microscope slides were obtained from Fisher Scientific. Selenoxide catalyst, Se1, was prepared according to the literature procedure (Bennett et al. 2008).

\section{Preparation of Te1 catalyst}

Preparation of 3-(tert-butyldimethylsilyloxypropyl) hexyl elluride (1)

1-Bromohexane $(0.85 \mathrm{ml}, 6.06 \mathrm{mmol})$ was dissolved in anhydrous tetrahydrofuran (THF, $25 \mathrm{ml}$ ) and tert-BuLi $(7.8 \mathrm{ml}$ of a $1.7 \mathrm{M}$ solution in THF, $13 \mathrm{mmol}$ ) was added dropwise via syringe at $-78^{\circ} \mathrm{C}$. After $1 \mathrm{~h}$, Te powder $(0.772 \mathrm{~g}, 6.06 \mathrm{mmol})$ was added

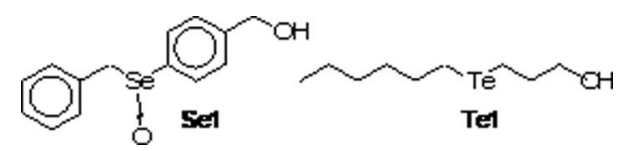

Chart 1. Chemical structures of selenoxide (Se1) and telluride (Te1) catalysts. 
and the resulting mixture was stirred for $15 \mathrm{~min}$ at $-78^{\circ} \mathrm{C}$ and was then stirred at room temperature until the Te was completely consumed. The reaction mixture was cooled to $-78^{\circ} \mathrm{C}, 3$-bromopropyloxy-tertbutyldimethylsilane $(1.82 \mathrm{~g}, 6.06 \mathrm{mmol})$ (Francavilla et al. 2000,2001) was added, and stirring was continued for $1 \mathrm{~h}$ at $-78^{\circ} \mathrm{C}$ and for $15 \mathrm{~h}$ at room temperature. The reaction mixture was poured into $150 \mathrm{ml}$ of water. The organic products were extracted with ether $(3 \times 40$ $\mathrm{ml})$. The ether extracts were washed with brine $(50 \mathrm{ml})$, dried over sodium sulphate, and concentrated. The product was purified via chromatography on $\mathrm{SiO}_{2}$ eluting with $30 \%$ dichloromethane in hexanes to give 3-(tert-butyldimethylsilyloxypropyl)hexyltelluride (1) as a yellow oil $(1.31 \mathrm{~g}, 56 \%):{ }^{1} \mathrm{H}$ NMR $(300 \mathrm{MHz}$, $\left.\mathrm{CDCl}_{3}\right) \delta 3.64(\mathrm{t}, 2 \mathrm{H}, J=6.0 \mathrm{~Hz}), 2.66(\mathrm{t}, 2 \mathrm{H}, J=7.8$ $\mathrm{Hz}$ ), 2.63 (t, $2 \mathrm{H}, J=7.8 \mathrm{~Hz}$ ), 1.94 (quint, $2 \mathrm{H}, J=7.2$ $\mathrm{Hz}$ ), 1.73 (quint, $2 \mathrm{H}, J=7.2), 1.27-1.35(\mathrm{~m}, 6 \mathrm{H})$, 0.88-0.89 (m, $12 \mathrm{H}), 0.05$ (s, $6 \mathrm{H}) ;{ }^{13} \mathrm{C}$ NMR $(75 \mathrm{MHz}$, $\left.\mathrm{CDCl}_{3}\right) \delta 64.2,35.2,32.2,31.7,31.2,25.9,22.5,18.3$, 14.0, 2.92, - 1.69, - 5.28; HRMS (EI) $m / z 388.1431$ (calcd for $\mathrm{C}_{15} \mathrm{H}_{34} \mathrm{OSiTe} 388.1441$ ).

\section{Preparation of 3-(n hexyltelluro)-1-propanol (Te1)}

Telluride 1 (1.04 g, $2.69 \mathrm{mmol})$ was dissolved in anhydrous THF $(30 \mathrm{ml})$ and stirred for $15 \mathrm{~min}$. Tetra$n$-butylammonium fluoride $(5.39 \mathrm{ml}$ of a $1 \mathrm{M}$ solution in THF, $5.39 \mathrm{mmol}$ ) was added dropwise over several minutes and the resulting solution was stirred for $2 \mathrm{~h}$ at room temperature. Excess saturated ammonium chloride $(50 \mathrm{ml})$ was added and the resulting mixture was stirred for an additional $10 \mathrm{~min}$. The reaction mixture was concentrated, water $(50 \mathrm{ml})$ was added, and the organic products were extracted with ethyl acetate $(3 \times 40 \mathrm{ml})$. The combined organic extracts were dried over sodium sulphate and concentrated to give a yellow oil, which was purified on $\mathrm{SiO}_{2}$ eluting with $10 \%$ ether in hexanes to give 3-( $n$-hexyltelluro)-1propanol (Te1) as a yellow oil $(0.39 \mathrm{~g}, 56 \%):{ }^{1} \mathrm{H}$ NMR $\left(300 \mathrm{MHz}, \mathrm{CDCl}_{3}\right) \delta 3.69(\mathrm{t}, 2 \mathrm{H}, J=6.0 \mathrm{~Hz}), 2.68(\mathrm{t}$, $2 \mathrm{H}, J=7.2 \mathrm{~Hz}$ ), $2.63(\mathrm{t}, 2 \mathrm{H}, J=7.2 \mathrm{~Hz}$ ), 1.99 (quint, $2 \mathrm{H}, J=6.6 \mathrm{~Hz}$ ), 1.73 (quint, $2 \mathrm{H}, J=7.2 \mathrm{~Hz}$ ), 1.26 $1.32(\mathrm{~m}, 6 \mathrm{H}), 0.90(\mathrm{t}, 3 \mathrm{H}, J=4.8 \mathrm{~Hz}) ;{ }^{13} \mathrm{C}$ NMR $(75$ $\left.\mathrm{MHz}, \mathrm{CDCl}_{3}\right) \delta 63.9,34.6,32.1,31.6,31.1,22.5,13.9$, $3.11,-2.18$; IR $3307 \mathrm{~cm}^{-1}$; HRMS (EI) $\mathrm{m} / z 274.0561$ (calcd for $\mathrm{C}_{9} \mathrm{H}_{20} \mathrm{OTe} 274.0576$ ).

\section{Preparation of glass control slides}

Plain $25 \mathrm{~mm} \times 75 \mathrm{~mm}$ borosilicate glass slides were cleaned by soaking in $1 \mathrm{~N} \mathrm{HCl}$ for $24 \mathrm{~h}$ and were then rinsed with copious amounts of deionised water and ethanol. These treated slides were dried under ambient conditions and used within 1 day.

\section{Sol preparation}

The sol/xerogel composition is designated in terms of the $\mathrm{mol} \%$ of Si-containing precursors. Thus, a 10/90 APTES/TEOS composition contains $10 \mathrm{~mol} \%$ APTES and $90 \mathrm{~mol} \%$ TEOS. The various sols and their abbreviations are summarised in Table 1.

\section{Sol TEOS}

TEOS $(3.130 \mathrm{~g}, 15.02 \mathrm{mmol}, 3.345 \mathrm{ml})$ was mixed with water $(0.54 \mathrm{ml})$, ethanol $(3.40 \mathrm{ml})$ and $15 \mu \mathrm{l}$ of $0.1 \mathrm{~N}$ $\mathrm{HCl}(1.5 \mu \mathrm{mol})$ in a sealed glass vial and stirred at room temperature for $6 \mathrm{~h}$.

\section{Sol APTES}

APTES (2.544 g, $11.49 \mathrm{mmol})$ was added dropwise to a stirring solution of $2 \mathrm{~g}$ of $6.67 \mathrm{~N} \mathrm{HCl}$ and ethanol (10.56 ml). Once addition was complete, the solution was sonicated at room temperature for $40 \mathrm{~min}$.

\section{Sol 10/90 APTES/TEOS (B6 xerogel)}

Sol APTES (5 ml) was added dropwise to a stirring mixture of Sol TEOS $(16.77 \mathrm{ml})$. The resulting mixture was sonicated at room temperature for $20 \mathrm{~min}$.

\section{Sol 10/90 APTES/TEOS with Se1 catalyst (B6Se1 xerogel)}

Selenoxide catalyst Se1 $(0.088 \mathrm{~g}, 0.300 \mathrm{mmol})$ was added to Sol 10/90 APTES/TEOS $(20.00 \mathrm{ml})$ and stirred at room temperature for $5 \mathrm{~min}$ to give $0.015 \mathrm{M}$ Se1 in Sol 10/90 APTES/TEOS.

\section{Sol 10/90 APTES/TEOS with Te1 catalyst (B6Te1 xerogel)}

Telluride catalyst Te1 $(0.096 \mathrm{~g}, 0.300 \mathrm{mmol})$ was added to Sol 10/90 APTES/TEOS $(20 \mathrm{ml})$ and stirred at room temperature for $5 \mathrm{~min}$ to give $0.015 \mathrm{M}$ Te1 in $10 / 90$ APTES/TEOS.

Table 1. Coating abbreviations used with the various sol formulations and catalyst combinations.

\begin{tabular}{lcc}
\hline Sol formulation & Catalyst & $\begin{array}{c}\text { Coating } \\
\text { abbreviation }\end{array}$ \\
\hline 50/50 APTES/TEOS & None & B5 \\
50/50 APTES/TEOS & $0.015 \mathrm{M}$ selenoxide Se1 & B5Se \\
50/50 APTES/TEOS & 0.015 M telluride Te1 & B5Te \\
10/90 APTES/TEOS & None & B6 \\
10/90 APTES/TEOS & 0.015 M selenoxide Se1 & B6Se \\
10/90 APTES/TEOS & 0.015 M telluride Te1 & B6Te \\
\hline
\end{tabular}


Sol 50/50 APTES/TEOS (B5 xerogel)

Sol APTES $(10 \mathrm{ml})$ was added dropwise to a stirring mixture of Sol TEOS $(3.73 \mathrm{ml})$. The resulting mixture was sonicated at room temperature for $20 \mathrm{~min}$.

\section{Sol 50/50 APTES/TEOS with Se1 catalyst (B5Se1 xerogel)}

Selenoxide catalyst Se1 $(0.088 \mathrm{~g}, 0.30 \mathrm{mmol})$ was added to Sol 50/50 APTES/TEOS $(20 \mathrm{ml})$ and stirred at room temperature for $5 \mathrm{~min}$ to give $0.015 \mathrm{M} \mathrm{Se1}$ in Sol 50/50 APTES/TEOS.

\section{Sol 50/50 APTES/TEOS with Te1 catalyst (B5Te1 xerogel)}

Telluride catalyst Te1 $(0.096 \mathrm{~g}, 0.30 \mathrm{mmol})$ was added to Sol 50/50 APTES/TEOS $(20 \mathrm{ml})$ and stirred at room temperature for $5 \mathrm{~min}$ to give $0.015 \mathrm{M}$ Te1 in $50 / 50$ APTES/TEOS.

\section{Xerogel film formation}

Xerogel films were formed by spin casting onto $25 \mathrm{~mm} \times 75 \mathrm{~mm}$ glass microscope slides. To form the film on the glass, a $0.4-\mathrm{ml}$ sample of a given sol solution was evenly delivered onto the entire surface of the slide, which was then placed in the spin coater. The spin coater was then engaged and the substrate rotated at $3000 \mathrm{rpm}$ for $30 \mathrm{~s}$. All films were stored under ambient conditions in the dark for at least 1 week prior to submission for settlement and removal assays.

\section{Film thicknesses}

Film thicknesses were determined by using a Tencor instruments, alpha-step 500 profilometer with a diamond-point stylus. Triplicate samples of each film type were measured. The film thicknesses reported represent the average and associated standard deviations (SDs). An uncoated section of substratum, obtained by placing Scotch tape across the substratum edge prior to film deposition, was used to establish a baseline.

\section{Evaluation of halide permeability in xerogel films}

The B5 and B6 xerogels described above were prepared from sols that were doped with the luminescent reporter molecule tris $\left(4,7^{\prime}\right.$-diphenyl-1,10'-phenanathroline)ruthenium(II) chloride $\left(\left[\mathrm{Ru}(\mathrm{dpp})_{3}\right]^{2+}\right)$ and the resulting xerogels were exposed to various concentrations of dissolved $\mathrm{I}^{-}$or $\mathrm{O}_{2}$, a quencher for luminescence (Tang et al. 2003). In the simplest scenario of a luminophore sequestered within a homogeneous medium, luminophore quenching obeys the Stern-Volmer relationship (Eftink1991; Lakowicz 1999):

$$
I_{0} / I_{\mathrm{Q}}=1+K_{\mathrm{SV}}[Q]=1+k_{\mathrm{q}} \tau_{\mathrm{o}}[Q]
$$

In this expression, $I_{0}$ and $I_{\mathrm{Q}}$ are the steady-state luminescence intensities in the absence and presence of quencher, respectively; $\tau_{0}$ is the excited-state luminophore lifetime in the absence of $Q ;[Q]$ is the quencher concentration; $K_{\mathrm{SV}}$ is the dynamic Stern-Volmer quenching constant; and $k_{\mathrm{q}}$ is the bimolecular rate constant that describes the efficiency of luminophorequencher collisional encounters. For this ideal case, a plot of $I_{0} / I_{\mathrm{Q}}$ versus $[Q]$ will be linear with a slope equal to $K_{\mathrm{SV}}$ and an intercept of unity. $K_{\mathrm{SV}}$ provides a convenient way to assess anion and neutral species transport within the films (Tang et al. 2003; Tao et al. 2006).

\section{Scanning electron microscope images}

Scanning electron microscope (SEM) images were recorded by using a Hitachi model S-800 field emission scanning electron microscope operating at a $25 \mathrm{kV}$ acceleration voltage. The xerogel films were overcoated with a 20-nm layer of evaporated carbon to maintain surface-charge continuity.

\section{$X$-ray photoelectron spectroscopy}

X-ray photoelectron spectroscopy (XPS) spectra were recorded using a Physical Electronics Laboratories (PHI) Model 5100 spectrometer equipped with a $\mathrm{Mg} / \mathrm{Ti}$ dual anode source, an $\mathrm{Al} / \mathrm{Be}$ window, a hemispherical analyser, and single channel channeltron detector. An achromatic Mg K- $\alpha$ X-ray (1253.6 eV) source was operated at $300 \mathrm{~W}, 15 \mathrm{kV}$ and $20 \mathrm{~mA}$. The system base pressure was no higher than $2 \times 10^{-8}$ torr, with an operating pressure that did not exceed $1 \times 10^{-7}$ torr. A pass energy of $89.45 \mathrm{eV}$ was used to obtain the survey spectra and $35.75 \mathrm{eV}$ was used for the high resolution, multi-region scans. Spectra were obtained at $45^{\circ}$ takeoff angles. The sampling depth for $\mathrm{C}$ and $\mathrm{Si}$ is $\sim 80-90$ $\AA$. The instrument was calibrated using $\mathrm{Mg} \mathrm{K}-\alpha$ $\mathrm{X}$-radiation such that the $\mathrm{Ag} 3 \mathrm{~d}_{5 / 2}$ peak of sputtered clean $\mathrm{Ag}$ had a binding energy of $367.9 \pm 0.1 \mathrm{eV}$ and the binding energy difference between the $\mathrm{Cu} 2 \mathrm{p}_{3 / 2}$ and Au $4 \mathrm{f}_{7 / 2}$ was $848.7 \pm 0.1 \mathrm{eV}$. The full width at half maximum for the $\mathrm{Ag} 3 \mathrm{~d}_{5 / 2}$ peak was $0.80 \mathrm{eV}$ at 30,000 counts $\mathrm{s}^{-1}$. Data manipulation was performed using a Perkin-Elmer 7500 professional computer running PHI ESCA Version 2.0 software.

Instrumental sensitivity allows ratios of masses of 0.01 to be measured at the surface. However, the $\mathrm{C}(1 \mathrm{~s}) / \mathrm{Si}(2 \mathrm{p} 3)$ ratio of 0.2 measured on glass indicates 
that this level of contamination with atmospheric carbon might be present in all samples and only values that are significantly larger than 0.2 for the $\mathrm{C}(1 \mathrm{~s}) /$ $\mathrm{Si}(2 \mathrm{p} 3)$ ratio have meaning. Background levels of $\mathrm{N}(1 \mathrm{~s}) / \mathrm{Si}(2 \mathrm{p} 3)$ were $<0.01$.

Xerogel coatings were soaked in artificial seawater (ASW) without or with $0.9 \mathrm{M} \mathrm{H}_{2} \mathrm{O}_{2}$ for $24 \mathrm{~h}$, were washed with distilled water, and air-dried for $24 \mathrm{~h}$ prior to XPS measurements.

\section{Cyprid settlement assays using $B$. amphitrite}

Thirty to 50 larvae were 'drop assayed' onto each of the replicate surfaces in ASW with and without 100 $\mu \mathrm{M}$ or $20 \mu \mathrm{M} \mathrm{H}_{2} \mathrm{O}_{2}$. Assays lasted $\sim 48 \mathrm{~h}$, although the exact duration depended on the time it took $50 \%$ of the larvae to settle (a mean settlement of 0.50) in the control standard, an uncoated glass slide. Stopping the assays after $\sim 50 \%$ of the larvae have settled on the control surfaces provides information on $\mathrm{AF}$ and inductive characteristics of the experimental coatings with respect to the rate of settlement on the surfaces. At the end of the initial assay period the numbers of larvae that successfully attached and metamorphosed were counted. Larvae that did not settle by the end of the $24 \mathrm{~h}$ period were observed for signs of abnormal behaviour to assess any compromise to normal physiological function. Fouling resistance was estimated by determining the fraction of individuals settling on each coating.

\section{Leaching assays for toxic compounds during cyprid settlement}

Coatings were soaked for 6 days in $100 \mathrm{ml}$ of ASW with and without added peroxide $(100 \mu \mathrm{M}$ or $20 \mu \mathrm{M})$ prior to settlement assays. The leachate was removed and replaced with $100 \mathrm{ml}$ of seawater at $72 \mathrm{~h}$ intervals. The leachate from coatings was used to conduct assays of survivorship with $\sim 200$ nauplii larvae of Artemia sp. (brine shrimp). The larvae were exposed to the coating leachate and their survival was monitored for 2 days. Survival of larvae in coating leachate was compared with leachate from a glass slide control.

\section{Assays for metamorphosis of larvae of $\mathrm{H}$. elegans}

Ten experimental coatings and uncoated glass microscope slides were rinsed with tap water and then placed in running seawater tables at the Kewalo marine laboratory for 7 days to develop a bacterial biofilm. After acquiring a biofilm, coatings were placed in plastic containers containing $19 \mathrm{ml}$ of natural seawater from the Kewalo site, ASW (MBL general purpose sea water, see Cavanaugh 1975), or a $5 \mu \mathrm{M}$ solution of
$\mathrm{H}_{2} \mathrm{O}_{2}$ in ASW. One millilitre of ASW containing competent larvae of $H$. elegans was added to each dish. These larvae were allowed to settle and metamorphose, and after $\sim 21 \mathrm{~h}$ the number of metamorphosed juveniles was determined for each of the coatings. Larvae were considered metamorphosed if they were permanently attached to the surface of the coatings and had begun to differentiate the branchial crown. The results of the experiment were analysed using a one-way ANOVA with Tukey's multiple pair-wise comparisons. The percentage of metamorphosed larvae for each replicate was subjected to angular transformation in order to comply with the assumptions of parametric analysis.

\section{Settlement assay for Ulva zoospores}

Zoospores of Ulva linza were released and prepared for the assay as previously described (Callow et al. 1997). The assay followed the principles outlined in Tang et al. (2005): $10 \mathrm{ml}$ aliquots $\left[1.5 \times 10^{6}\right.$ spore $\mathrm{ml}^{-1}$ in ASW with and without $100 \mu \mathrm{M} \mathrm{H}_{2} \mathrm{O}_{2}$ ] were pipetted into individual compartments of polystyrene quadriperm culture dishes (Fisher), each containing a test surface. After incubation for $1 \mathrm{~h}$ in darkness at $\sim 20^{\circ} \mathrm{C}$, all slides were washed in ASW to remove zoospores that had not attached. After fixation, the density of zoospores attached to the surface was counted on each of three replicate slides using an image analysis system attached to a fluorescent microscope. Means $(x=90)$ and $95 \%$ confidence limits (two SDs) were calculated and expressed as mean number of attached (settled) spores $\mathrm{mm}^{-2}$. Data were analysed by one-way ANOVA followed by a pairwise Tukey test.

\section{Results}

\section{Characterisation of xerogel surfaces}

Key to the success of the current platform is the ability of the reagents (halide and $\mathrm{H}_{2} \mathrm{O}_{2}$ ) and products (hypohalous acid) to partition and diffuse within the xerogel film. Transport of small neutral molecules within these types of xerogels has been investigated previously (Tang et al. 2003; Tao et al. 2006). A screening campaign showed that there was significant $I^{-}$quenching of $\left[\mathrm{Ru}(\mathrm{dpp})_{3}\right]^{2+}$ within the $50 \%$ APTES/ $50 \%$ TEOS (B5) and the $10 \%$ APTES $/ 90 \%$ TEOS xerogel (B6) formulations. Figure 1 compares the Stern-Volmer plots for $I$ quenching of $\left[\mathrm{Ru}(\mathrm{dpp})_{3}\right]^{2+}$ in solution, $\left[\mathrm{Ru}(\mathrm{dpp})_{3}\right]^{2+}$ sequestered within a $\mathrm{B} 5$ xerogel film, and $\left[\mathrm{Ru}(\mathrm{dpp})_{3}\right]^{2+}$ sequestered within a hydrophobic xerogel film prepared from a 50/50 npropyltriethoxysilane (C3TMOS)/TMOS) sol, which has been described as an $\mathrm{AF} /$ foul-release surface 


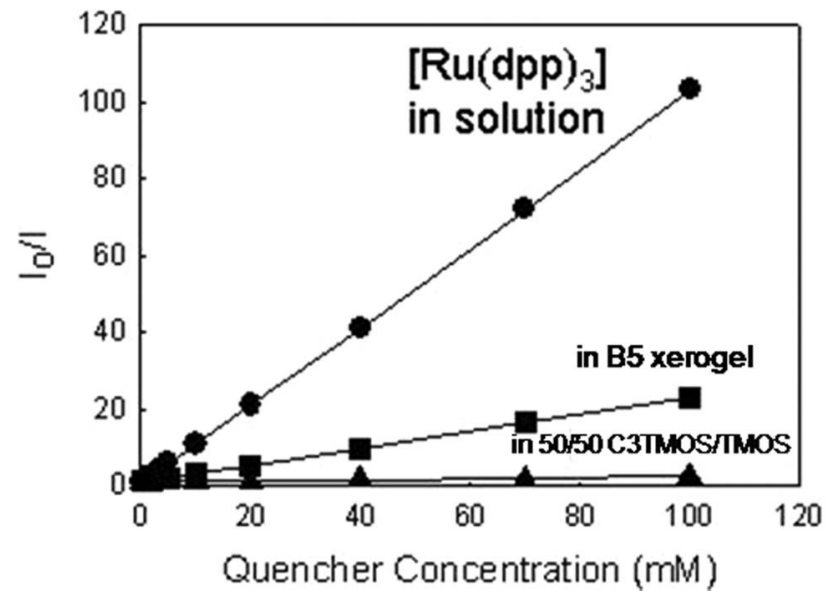

Figure 1. Stern-Volmer quenching of $\left[\mathrm{Ru}(\mathrm{dpp})_{3}\right]^{2+}$ by aqueous potassium iodide in aqueous solution, in xerogel $\mathrm{B} 5$ and in xerogel 50/50 C3TMOS/TMOS where the slope of each line equals $K_{\mathrm{SV}}$.

(Tang et al. 2005). The hydrophobic 50/50 C3TMOS/ TMOS- $\left[\mathrm{Ru}(\mathrm{dpp})_{3}\right]^{2+}$ formulation did not show significant quenching, suggesting that the $I^{-}$cannot partition/diffuse within this film. The $I^{-}$can clearly partition into and diffuse within the B5 xerogel. (Note: Similar behavior is seen in the B6 xerogel.)

The B5 xerogel yielded a very hydrophilic surface with water-contact angles $\left(\theta_{\mathrm{w}}\right)$ of $34 \pm 1^{\circ}$. The B6 xerogel formulation was less hydrophilic with $\theta_{\mathrm{w}}$ of $54 \pm 1^{\circ}$.

Profilometry showed that the xerogel films were $1.0 \pm 0.1 \mu \mathrm{m}$ thick. Although such thin films would not likely be a 'practical' surface for marine deployment, the uniformity offered by the 'spin casting method' provides a model surface that can be reproduced lot to lot.

The class II xerogel (a metal tetraalkoxide and a metal trialkoxide covalently bound; ie TEOS and APTES for the B5 and B6 xerogels of this study) film surfaces are more uniform and uncracked in comparison with xerogels derived from pure TMOS or TEOS (Tang et al. 2003). The incorporation of organic functional groups in the hybrid xerogels reduces crosslinking in the silicate structure from $\mathrm{Si}(\mathrm{OSi} \equiv)_{4}$ in the pure TMOS or TEOS to $\mathrm{RSi}(\mathrm{OSi} \equiv)_{3}$ in the class II xerogels leading to a more flexible, less friable surface. SEM analysis of the B5 and B6 xerogels with and without catalysts showed them to be uniform and uncracked at magnifications up to $100,000 \times$ with resolution of $200 \mathrm{~nm}$.

XPS spectra of the B6 xerogel film were recorded at a take-off angle of $45^{\circ}$ to determine the atomic composition at the surface of the xerogel coating/film after treatment of the surface with ASW and with $0.9 \mathrm{M}$ $(3 \%) \mathrm{H}_{2} \mathrm{O}_{2}$ in ASW. The results are shown in Figure 2.

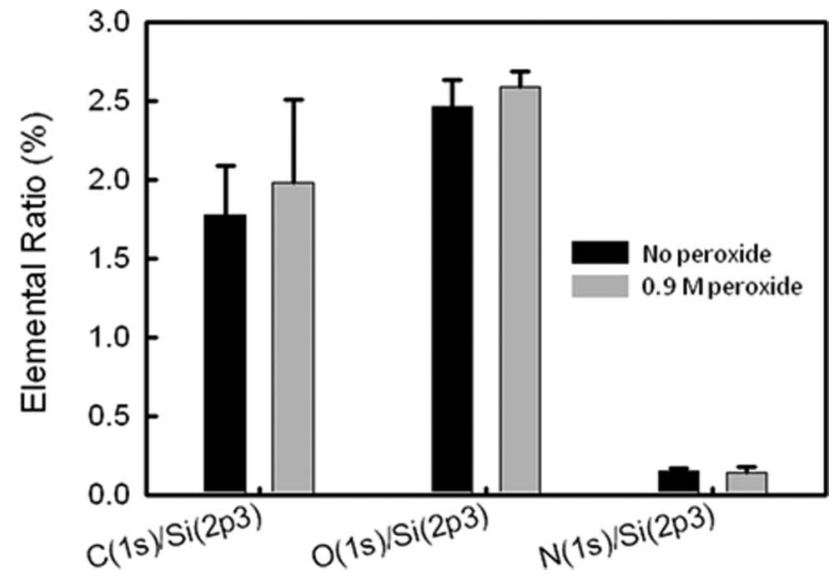

Figure 2. Effect of $0.9 \mathrm{M} \mathrm{H}_{2} \mathrm{O}_{2}$ on 10/90 APTES/TEOS (B6) xerogel as determined by XPS. Mean of three independent measurements for coatings exposed to ASW with and without $0.9 \mathrm{M} \mathrm{H}_{2} \mathrm{O}_{2}$ for $24 \mathrm{~h}$ prior to measurement. Imprecision is reported as \pm 2 SDs ( $95 \%$ confidence limits) from three independent measurements.

In glass, the ratio of the $\mathrm{C}(1 \mathrm{~s}) / \mathrm{Si}(2 \mathrm{p} 3)$ signals is 0.2 (Tang et al. 2005), suggesting a relatively carbon-free surface with any carbon found at the ostensibly $\mathrm{SiO}_{2}$ surface presumably arising from adventitious/ adsorbed carbon-containing species from the atmosphere. The ratio of the $\mathrm{C}(1 \mathrm{~s}) / \mathrm{Si}(2 \mathrm{p} 3)$ signals for the $\mathrm{B} 6$ xerogel surface is $1.75 \pm 0.30$ for the surface treated with ASW and $2.0 \pm 0.5$ for the surface treated with $0.9 \mathrm{M} \mathrm{H}_{2} \mathrm{O}_{2}$ in ASW for $24 \mathrm{~h}$ prior to XPS analysis. Exposure to $\mathrm{H}_{2} \mathrm{O}_{2}$ has little effect on the ratio of the $\mathrm{O}(1 \mathrm{~s}) / \mathrm{Si}(2 \mathrm{p} 3)$ signals with values of $2.45 \pm 0.20$ in the sample exposed to ASW and $2.55 \pm 0.10$ in the sample exposed to $0.9 \mathrm{M} \mathrm{H}_{2} \mathrm{O}_{2}$ in ASW. The ratio of the $\mathrm{N}(1 \mathrm{~s}) /$ $\mathrm{Si}(2 \mathrm{p} 3)$ signals was also unchanged by the exposure of the sample to $\mathrm{H}_{2} \mathrm{O}_{2}$ with values of $0.20 \pm 0.02$ in ASW and $0.20 \pm 0.05$ in the sample exposed to $0.9 \mathrm{M} \mathrm{H}_{2} \mathrm{O}_{2}$ in ASW. The ratio of the $\mathrm{N}(1 \mathrm{~s}) / \mathrm{Si}(2 \mathrm{p} 3)$ are well above the background signals of $<0.01$. These results suggest that carbon- and nitrogen-bearing functionalities are on the class II xerogel film surface.

Figure 3 shows high-resolution XPS spectra of the $\mathrm{N}(1 \mathrm{~s})$ signals of the B6 xerogel from samples exposed to ASW with and without added $0.9 \mathrm{M} \mathrm{H}_{2} \mathrm{O}_{2}$. The experimental spectra were resolved into two peaks at $404.5 \mathrm{eV}$ and $402.6 \mathrm{eV}$ in a ratio of $65: 35$ in ASW without added peroxide and 67:33 in ASW with $0.9 \mathrm{M}$ $\mathrm{H}_{2} \mathrm{O}_{2}$. The presence of $\mathrm{H}_{2} \mathrm{O}_{2}$ had minimal effect on the type of nitrogen-containing functionality found on the xerogel surface.

\section{Settlement of $B$. amphitrite cypris larvae}

Settlement of cyprids on glass in ASW with $100 \mu \mathrm{m}$ $\mathrm{H}_{2} \mathrm{O}_{2}$ was not statistically different from settlement on 

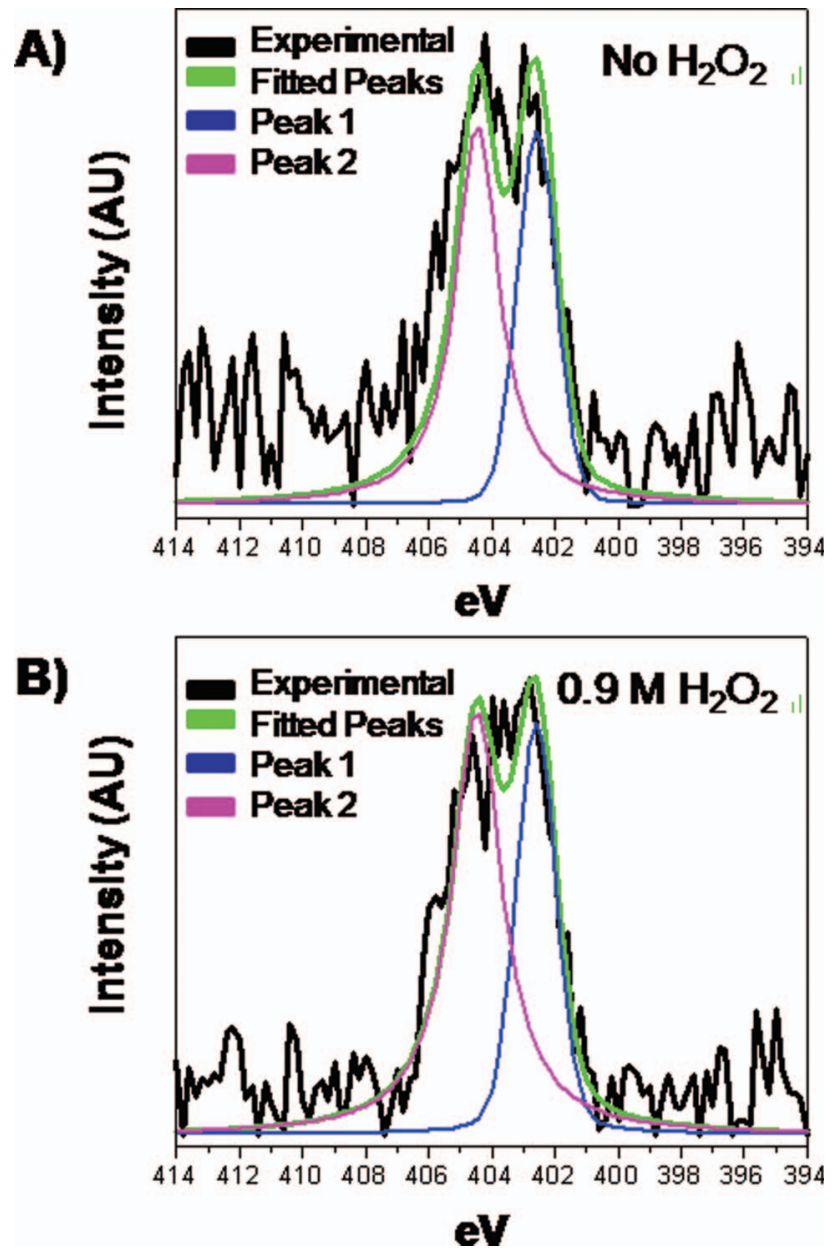

Figure 3. High resolution XPS spectra (black) of the N(1s) region of the 10/90 APTES/TEOS (B6) xerogel exposed for $24 \mathrm{~h}$ to $\mathrm{ASW}$ (A) without and (B) with $0.9 \mathrm{M} \mathrm{H}_{2} \mathrm{O}_{2}$. The spectra were deconvoluted to give two component peaks at $404.5 \mathrm{eV}$ (pink) and $402.6 \mathrm{eV}$ (blue) in a ratio of (A) 65:35 and (B) 67:33. Fitted spectra are shown in green.

glass in ASW without $\mathrm{H}_{2} \mathrm{O}_{2}$ indicating that peroxide did not have any detrimental effect on settlement. Settlement was completely inhibited on the B6, B6Se and B6Te xerogels in the presence of $100 \mu \mathrm{M}$ peroxide in ASW. The settlement of $B$. amphitrite cypris larvae on the 50/50 APTES/TEOS (B5, B5Se and B5Te) and 10/90 APTES/TEOS (B6, B6Se and B6Te) hybrid xerogels was significantly lower in comparison with the glass controls in the presence of $100 \mu \mathrm{M}$ peroxide (Figure 4, ANOVA $p<0.0001$ ). Settlement was also significantly less in comparison with the glass controls in the absence of $100 \mu \mathrm{M}$ peroxide on the $\mathrm{B} 6, \mathrm{~B} 6 \mathrm{Se}$ and B6Te xerogels. The B5Te xerogel showed significantly lower settlement $(p<0.05)$ in the presence of $100 \mu \mathrm{M}$ peroxide when compared with ASW alone.

Mortality of brine shrimp larvae exposed to the leachates from the 50/50 APTES/TEOS (B5, B5Se and

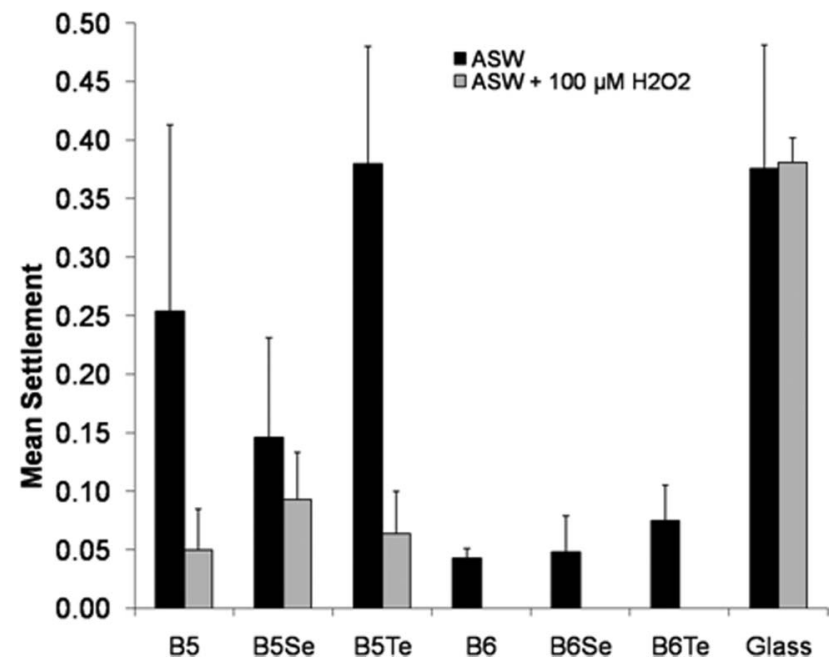

Figure 4. The fraction settlement of $B$. amphitrite cypris larvae on glass controls and B5 and B6 xerogel surfaces in ASW and ASW $+100 \mu \mathrm{M} \mathrm{H} \mathrm{H}_{2} \mathrm{O}_{2}$. B6, B6Te and B6Se showed zero settlement upon exposure to $100 \mu \mathrm{M} \mathrm{H}_{2} \mathrm{O}_{2}$. Experimental details may be found in the Materials and methods section. Error bars represent $1 \mathrm{SD}$ from the mean.

B5Te) and 10/90 APTES/TEOS (B6, B6Se and B6Te) hybrid xerogels in ASW with and without added $0.9 \mathrm{M}$ hydrogen peroxide was not significantly different $(p>0.05)$ in comparison with the mortality of larvae exposed to leachates from the glass controls. The glass controls showed no effect of the $100 \mu \mathrm{M} \mathrm{H}_{2} \mathrm{O}_{2}$ hydrogen peroxide on the mortality of brine shrimp nauplii larvae.

When the $\mathrm{H}_{2} \mathrm{O}_{2}$ concentration was reduced to $20 \mu \mathrm{M}$ in ASW, larvae of $B$. amphitrite showed significantly reduced settlement $(p<0.05)$ on B5Se and B5Te xerogels in comparison with glass controls and B5 coatings without catalysts (Figure 5). In the B6 series, both the B6 and B6Te coatings had significantly lower settlement in comparison with glass controls in the presence and absence of $\mathrm{H}_{2} \mathrm{O}_{2}(p<0.05)$. Settlement on the B6Se coating was not significantly different in the presence or absence of $20 \mu \mathrm{M} \mathrm{H}_{2} \mathrm{O}_{2}$ and was not significantly different from the glass controls $(p>0.05)$.

\section{Settlement of $\mathrm{H}$. elegans}

At peroxide concentrations of $20 \mu \mathrm{M}$ or higher, settlement and metamorphosis of larvae of $H$. elegans were not observed on glass standards. Consequently, the $\mathrm{H}_{2} \mathrm{O}_{2}$ concentration in ASW was reduced to $5 \mu \mathrm{M}$. At this concentration there were no significant differences relative to peroxide-free ASW in settlement (Figure 6) or metamorphosis of $H$. elegans on uncoated glass.

A number of coatings performed as AF coatings with respect to settlement of $H$. elegans when compared with uncoated glass slides. Replicate coatings of 
B5Se and B5Te performed significantly better (Tukey's pair-wise comparisons, $p<0.05$ ) in comparison with uncoated glass in the ASW only treatments (Figure 6), and settlement on coating B6Te was significantly lower $(p<0.05)$ in comparison with uncoated glass in the treatments with ASW containing $5 \mu \mathrm{M} \mathrm{H}_{2} \mathrm{O}_{2}$ (Figure 6).

\section{Settlement of Ulva zoospores}

Ulva zoospore settlement density on glass in ASW was unaffected by the presence of $100 \mu \mathrm{M} \mathrm{H}_{2} \mathrm{O}_{2}$. In addition, there was no subsequent effect on viability (germination and growth) by the presence of this concentration of peroxide. The presence or absence of $100 \mu \mathrm{M} \mathrm{H}_{2} \mathrm{O}_{2}$ had no effect on the density of settled spores on either of the control xerogel surfaces, B5 or B6 in ASW. None of the leachates from the xerogel films in ASW with or without added peroxide were toxic to Ulva zoospores.

Spore settlement was lower on all of the xerogel coatings in comparison with the glass standards (Figure 7). Settlement was lower on the B6 control coatings in comparison with the B5 control coatings. One-way analysis of variance showed significant differences within the xerogel data set $(p<0.01)$. Comparing the samples with and without additional $\mathrm{H}_{2} \mathrm{O}_{2}$ showed no significant differences except in the case of the B5Te coating.

The inclusion of the Se1 catalyst did not significantly affect the performance of either of the control xerogel coatings (B5 and B6). However, for both coating types, the inclusion of the Te1 catalyst

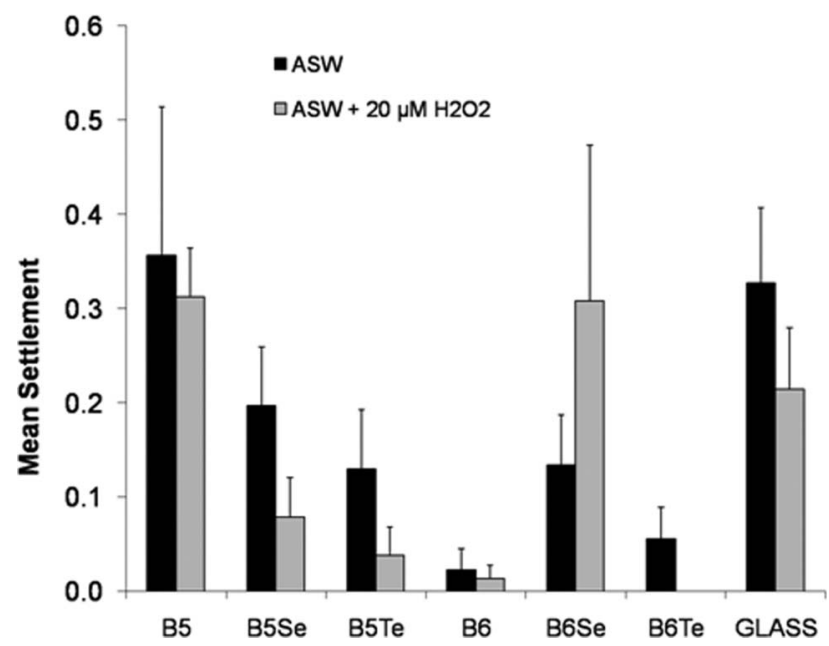

Figure 5. The fraction settlement of $B$. amphitrite cypris larvae on glass controls and B5 and B6 xerogel surfaces in ASW and ASW $+20 \mu \mathrm{M} \mathrm{H}_{2} \mathrm{O}_{2}$. Experimental details may be found in the Materials and methods section. Error bars represent $1 \mathrm{SD}$ from the mean. significantly reduced the settlement density of spores. In the case of the B5Te coating, spore density was further reduced by the presence of $100 \mu \mathrm{M} \mathrm{H}_{2} \mathrm{O}_{2}$.

\section{Discussion}

\section{'Active' xerogel surfaces}

The design of 'active' xerogel coatings for use as AF surfaces requires (1) the design of catalysts that activate ambient $\mathrm{H}_{2} \mathrm{O}_{2}$ and that can be covalently sequestered within the xerogel coating and (2) xerogel coatings that are permeable to the reagents necessary for activity. The APTES-containing B5 and B6 xerogels showed strong Stern-Volmer quenching of sequestered $\left[\mathrm{Ru}(\mathrm{dpp})_{3}\right]^{2+}$ by $\mathrm{I}^{-}$. Values of $K_{\mathrm{SV}}$ were $>200 \mathrm{M}^{-1}$ for these xerogels (xerogel 2 of Figure 1). In contrast, the 50/50 C3TMOS/TMOS xerogel (Tang et al. 2005) gave $K_{\mathrm{SV}}$ of $<20 \mathrm{M}^{-1}$. Values of $K_{\mathrm{SV}}$ for the $\mathrm{B} 5$ and

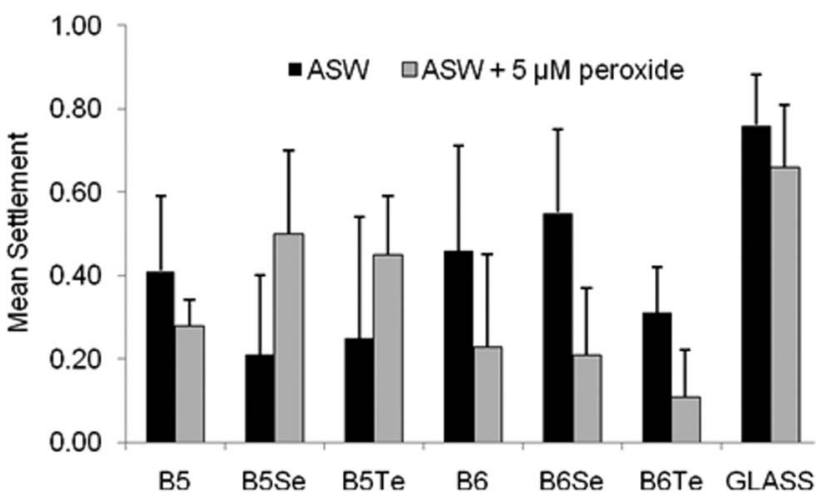

Figure 6. Effect of $5 \mu \mathrm{M} \mathrm{H}_{2} \mathrm{O}_{2}$ on the fraction settlement of H. elegans. Bars represent untransformed mean of replicate coatings. Experimental details may be found in the Materials and methods section. Error bars represent $1 \mathrm{SD}$ from the mean of the untransformed data.

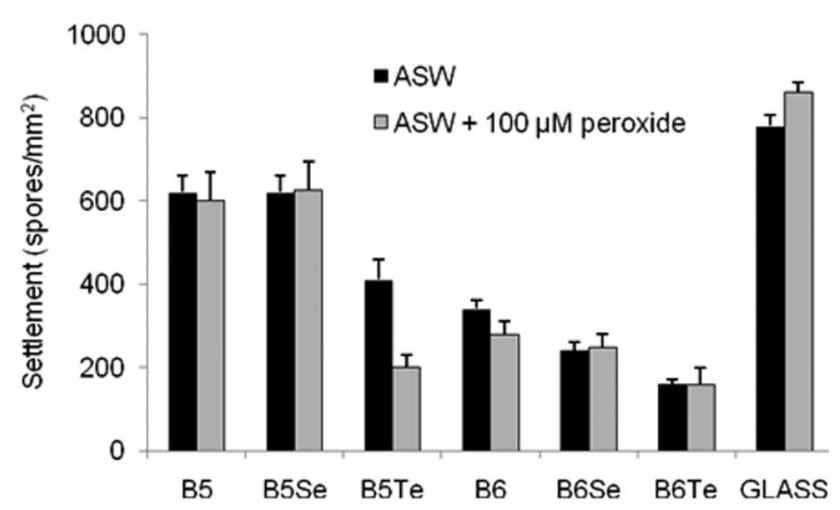

Figure 7. The settlement of Ulva zoospores on xerogel coatings in ASW and ASW $+100 \mu \mathrm{M} \mathrm{H}_{2} \mathrm{O}_{2}$. Each histogram bar is the mean from 90 counts, 30 from each of three replicate slides. Experimental details may be found in the Materials and methods section. Error bars represent 2 SDs from the mean ( $95 \%$ confidence limits). 
B6 xerogels suggest that the B5 and B6 coatings are much more permeable to $\mathrm{I}^{-}$and presumably other halide salts relative to the hydrophobic $50 / 50$ C3TMOS/TMOS xerogel (Tang et al. 2005). Although the 50/50 C3TMOS/TMOS xerogel might provide better foul release, the lack of permeability to halide ions would limit the effectiveness of this material in 'active' coatings. The alcohol functionality of the Te1 and Se1 catalysts allows these molecules to be sequestered covalently within the B5 and B6 xerogels.

Both organotelluides and selenoxides can function as catalysts for the oxidation of halide salts by $\mathrm{H}_{2} \mathrm{O}_{2}$. Organotellurides are oxidised by $\mathrm{H}_{2} \mathrm{O}_{2}$ to the corresponding telluroxides, which are then hydrated to give the corresponding dihydroxy telluranes A (Figure 8A). The dihydroxy telluranes function as mild oxidants for
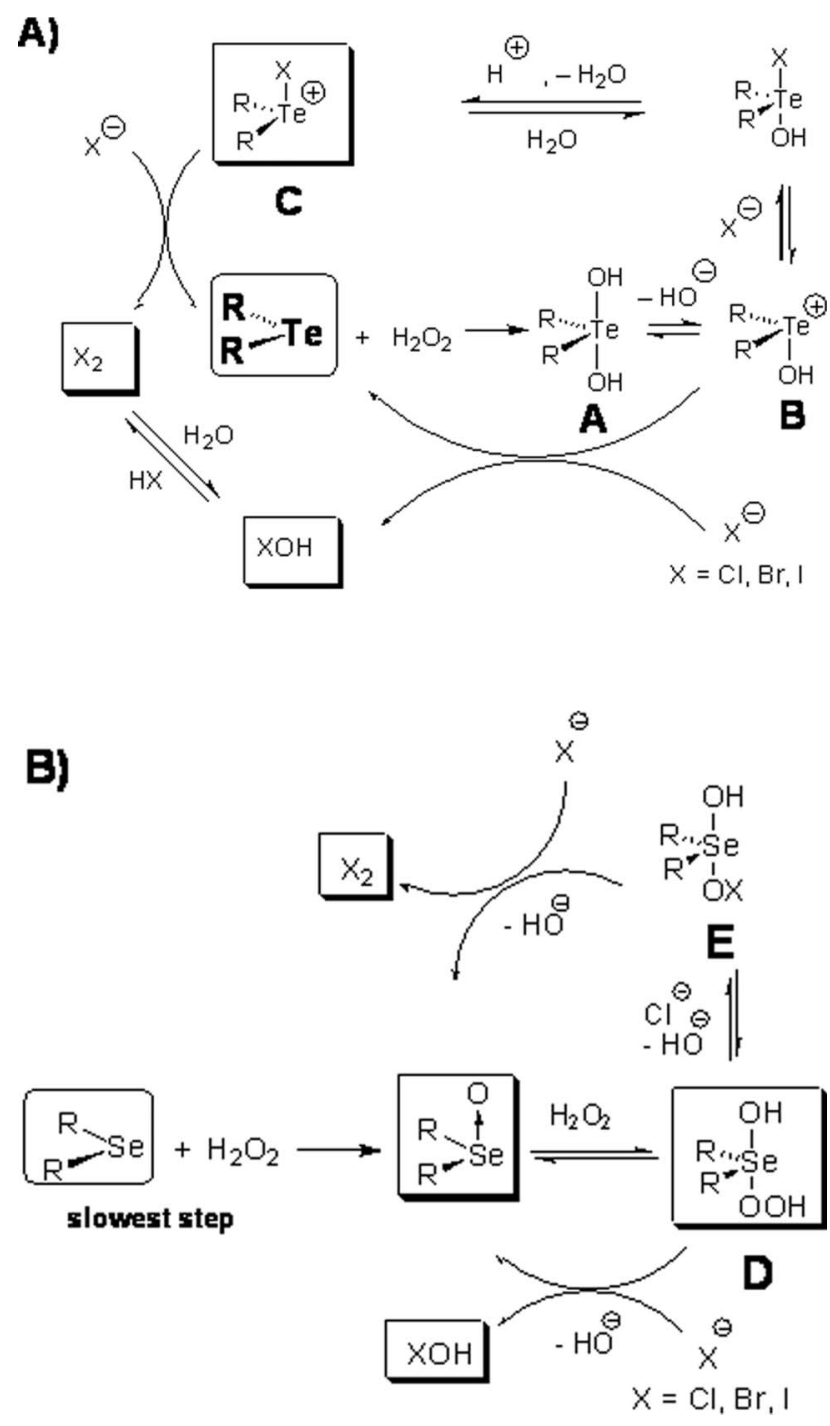

Figure 8. Catalytic cycles for the oxidation of halides salts with $\mathrm{H}_{2} \mathrm{O}_{2}$ using (A) organotelluride catalysts and (B) selenoxide catalysts. the oxidation of thiols to disulphides and for the oxidation of halides to positive halogen species (Detty et al. 1994a,b, 1996; You et al. 2003). The overall process can be made catalytic in organotelluride as shown in Figure 8A for the oxidation of halides to hypohalous acids/halogens (Detty et al. 1996; Higgs et al. 2001; Abe et al. 2002; You et al. 2003). Two key intermediates are the hydroxytelluronium ion $\mathrm{B}$ and the halotelluronium ion C (Detty et al. 1994b), which can generate hypohalous acid or halogen, respectively, by direct nucleophilic attack of halide as shown in Figure 8A.

Subsequent studies with selenoxides demonstrated that selenoxides are catalysts for the activation of $\mathrm{H}_{2} \mathrm{O}_{2}$ for the oxidation of halides to hypohalous acids/ halogen and thiols to disulphides (Drake et al. 2003; Goodman and Detty 2004). This process follows a different mechanism than that followed by the tellurides and is illustrated in Figure 8B. Just as telluroxides can add water to give dihydroxy telluranes, selenoxides can add $\mathrm{H}_{2} \mathrm{O}_{2}$ to give hydroxy perhydroxy selenanes D. In one path, halide anions can directly displace hydroxide from the perhydroxy group by attacking the $\mathrm{OOH}$ oxygen to give hypohalous acid and an $\mathrm{R}_{2} \mathrm{Se}(\mathrm{OH}) \mathrm{O}^{-}$species, which can lose $\mathrm{HO}^{-}$to regenerate the selenoxide. In a second pathway, halide attack at the $\underline{\mathrm{OOH}}$ oxygen of the perhydroxy selenane would generate an $\mathrm{R}_{2} \mathrm{Se}(\mathrm{OH}) \mathrm{OX}$ species $\mathbf{E}$, which can undergo attack by halide to generate halogen and an $\mathrm{R}_{2} \mathrm{Se}(\mathrm{OH}) \mathrm{O}^{-}$species, which can lose $\mathrm{HO}^{-}$to regenerate the selenoxide.

\section{Effects of $\mathrm{H}_{2} \mathrm{O}_{2}$ on the physical characteristics of xerogel surfaces}

Settlement of B. amphitrite cyprids, H. elegans larvae and Ulva zoospores was reduced relative to glass controls on the catalyst-free B6 xerogel coating in ASW without added $\mathrm{H}_{2} \mathrm{O}_{2}$. Settlement of $H$. elegans larvae and Ulva zoospores was reduced relative to glass controls on the catalyst-free B5 xerogel coating in ASW without added $\mathrm{H}_{2} \mathrm{O}_{2}$. The presence of $100 \mu \mathrm{M}$ $\mathrm{H}_{2} \mathrm{O}_{2}$ in the ASW gave further reduction in settlement in the catalyst-free $\mathrm{B} 5$ and $\mathrm{B} 6$ xerogels for $\mathrm{B}$. amphitrite cyprids. It might be asked whether the $\mathrm{H}_{2} \mathrm{O}_{2}$ is causing a chemical transformation in the xerogel, which further reduces the settlement.

The APTES aminopropyl groups are the organic residues of interest within the $\mathrm{B} 5$ and $\mathrm{B} 6$ xerogel coatings for two different reasons. First, these residues could organise randomly in the sol particles/xerogels, could lie on the surface of the sol particles/xerogels, or could organise within the sol. Furthermore, interactions with $\mathrm{H}_{2} \mathrm{O}_{2}$ could alter the orientation of the aminopropyl groups in the xerogel. Second, the 

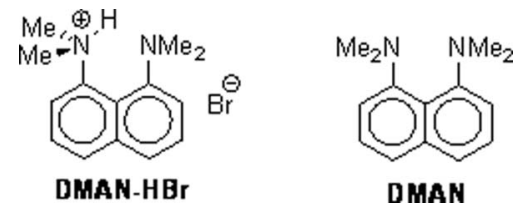

Chart 2. Chemical structures of protonated (DMAN-HBr) and unprotonated (DMAN) 1,8-bis(dimethylamino) naphthalene.

aminopropyl groups can be protonated in an aqueous environment ( $\mathrm{p} K_{\mathrm{a}}$ of $\sim 9-10$ for a primary ammonium group) or can be oxidised to imine groups using $\mathrm{H}_{2} \mathrm{O}_{2}$ as an oxidant. As shown in Figure 2, the $\mathrm{C}(1 \mathrm{~s}) / \mathrm{Si}(2 \mathrm{p} 3)$, $\mathrm{O}(1 \mathrm{~s}) / \mathrm{Si}(2 \mathrm{p} 3)$ and $\mathrm{N}(1 \mathrm{~s}) / \mathrm{Si}(2 \mathrm{p} 3)$ ratios were unchanged on the xerogel surfaces exposed to $0.9 \mathrm{M} \mathrm{H}_{2} \mathrm{O}_{2}$ in ASW relative to those exposed to ASW only. These data suggest that there is no significant surface reorganisation of functional groups containing carbon, oxygen or nitrogen upon exposure to $\mathrm{H}_{2} \mathrm{O}_{2}$. The highresolution N(1s) XPS data (Figure 3) showed the presence of two peaks centered at $404.5 \mathrm{eV}$ and $402.6 \mathrm{eV}$ in a $65: 35$ ratio following exposure to ASW and in a nearly identical 67:33 ratio following exposure to ASW with $0.9 \mathrm{M} \mathrm{H}_{2} \mathrm{O}_{2}$. These data indicate that the oxidising environment has little effect on the ratio of the two peaks and suggest that oxidation of the amines is not occurring to a significant degree. A more likely scenario is that the two peaks represent primary ammonium $(404.5 \mathrm{eV})$ and primary amino $(402.6 \mathrm{eV})$ groups from the APTES residues on the xerogel surface. The $1.9 \mathrm{eV}$ separation between the two $\mathrm{N}(1 \mathrm{~s})$ peaks is similar to the $2.5 \mathrm{eV}$ separation observed between the $\mathrm{N}(1 \mathrm{~s})$ peaks for a protonated $(402.0 \mathrm{eV})$ and unprotonated $(399.5 \mathrm{eV})$ dimethylamino group in protonated 1,8-bis(dimethylamino)-naphthalene (DMAN-HBr) (Bruckner et al. 1999) (Chart 2). Unprotonated DMAN shows a single $\mathrm{N}(1 \mathrm{~s})$ peak at $399.5 \mathrm{eV}$.

\section{Settlement on xerogel surfaces in the absence of $\mathrm{H}_{2} \mathrm{O}_{2}$}

Ammonium groups from APTES residues on the xerogel surface might serve to discourage the settlement of various organisms even in the absence of $\mathrm{H}_{2} \mathrm{O}_{2}$. Ammonium compounds have been incorporated in polymers and in marine paints and have been shown to give reduced fouling (Baudrion et al. 2000; Cowie et al. 2006). Settlement on the B6 xerogels (B6, $\mathrm{B} 6 \mathrm{Se}$ and $\mathrm{B} 6 \mathrm{Te}$ ) in the absence of peroxide was significantly less than on glass controls for both cypris larvae of B. amphitrite (Figures 4 and 5) and for Ulva zoospores (Figure 7).

In the absence of peroxide, both the B5Se and B5Te coatings showed reduced settlement $(p<0.05)$ of H. elegans relative to glass controls in ASW whereas the catalyst-free B5 xerogel did not (Figure 6). Prior to settlement studies with $H$. elegans, all of the xerogel coatings were left in natural seawater for 7 days to establish a biofilm on the surfaces prior to assay. Although the biofilm was not characterised, it is possible that peroxide-producing organisms (Chandrasekaran and Dexter 1993; Le Bozec et al. 2001; Dexter et al. 2003) might activate the B5Se and B5Te hybrid xerogels by producing hydrogen in the biofilm to discourage settlement in the ASW-only experiments whereas the catalyst-free B5 control would not be able to utilise the $\mathrm{H}_{2} \mathrm{O}_{2}$. Although the subsequent addition of $5 \mu \mathrm{M}$ peroxide had no statistically significant effect on settlement in these coatings, local concentrations of peroxide from the biofilm could be significantly higher (Chandrasekaran and Dexter 1993; Le Bozec et al. 2001; Dexter et al. 2003).

\section{Effect of $\mathrm{H}_{2} \mathrm{O}_{2}$ on settlement onto xerogel surfaces}

With respect to the settlement of cypris larvae of B. amphitrite, the presence of $100 \mu \mathrm{M} \mathrm{H}_{2} \mathrm{O}_{2}$ reduced settlement of both catalyst-free and catalyst-containing xerogels below that of glass controls (Figure 4). In the B5Te coating, settlement in the presence of $100 \mu \mathrm{M}$ $\mathrm{H}_{2} \mathrm{O}_{2}$ was significantly lesser than settlement on the same surface in ASW without peroxide. The B6 series of coatings was surprisingly efficient at discouraging settlement in the absence and presence of $100 \mu \mathrm{M}$ $\mathrm{H}_{2} \mathrm{O}_{2}$ with settlement on all surfaces being $<20 \%$ of glass controls. In the presence of the peroxide, no settlement was observed on B6, B6Se and B6Te xerogels. The reduced settlement did not appear to be because of any adverse physiological effect upon the barnacle larvae: cyprids were active and behaving normally on all coatings for the duration of the test. This observation is further supported by the lack of mortality among brine shrimp nauplii larvae exposed to the leachates from the two series of B5 and B6 xerogel coatings in the presence or absence of $100 \mu \mathrm{M}$ $\mathrm{H}_{2} \mathrm{O}_{2}$. Toxic substances are not leaching from the xerogel surfaces into bulk solution.

When the concentration of $\mathrm{H}_{2} \mathrm{O}_{2}$ was reduced to 20 $\mu \mathrm{M}$ in ASW, the difference between ASW only and ASW plus peroxide exposures was less pronounced (Figure 5). However, the B5Se and B5Te coatings in the presence of peroxide showed significantly reduced settlement in comparison with the B5 coating without catalyst and relative to glass controls. In the B6 series, the B6Te xerogel still showed no settlement by cypris larvae of $B$. amphitrite in the presence of 20 $\mu \mathrm{M} \mathrm{H}_{2} \mathrm{O}_{2}$, which is indicative of a highly inhibitory surface. 
The settlement of H. elegans on the B6Te xerogel was also significantly impacted by the presence of $\mathrm{H}_{2} \mathrm{O}_{2}$ (Figure 6). In the presence of $5 \mu \mathrm{M} \mathrm{H}_{2} \mathrm{O}_{2}$, the trend shows that settlement was lower on the $\mathrm{B} 6$, B6Se and B6Te coatings in comparison with glass controls although only the reduced settlement on the B6Te coating in the presence of $5 \mu \mathrm{M} \mathrm{H}_{2} \mathrm{O}_{2}$ is statistically significant $(p<0.05)$. In the $\mathrm{B} 5$ series of xerogels, the catalyst had no significant impact on settlement relative to the $\mathrm{B} 5$ control in the presence of $5 \mu \mathrm{M}$ $\mathrm{H}_{2} \mathrm{O}_{2}$.

The settlement of Ulva zoospores on all of the xerogel surfaces was significantly lower than on the glass standard in both the absence and presence of 100 $\mu \mathrm{M} \mathrm{H}_{2} \mathrm{O}_{2}$ in ASW. However, only the B5Te xerogel in the presence of $100 \mu \mathrm{M} \mathrm{H}_{2} \mathrm{O}_{2}$ in ASW gave significantly reduced settlement $(p<0.05)$ of Ulva zoospores relative to settlement on the B5Te xerogel in ASW in the absence of peroxide (Figure 7).

Surface energy and surface wettability are important characteristics for settlement cues and fouling release (Rittschof and Costlow 1989; Baier and Meyer 1992; Gerhart et al. 1992; Rittschof et al. 1998; Genzer and Efimenko 2006). With the xerogels, the present authors have found that lower-energy surfaces (or surfaces with a higher water contact angle) give reduced settlement as well as increased removal of various fouling organisms (Tang et al. 2005). The APTEScontaining xerogels are made more 'hydrophobic' by reducing the amount of APTES in the formulation. The $10 \%$ APTES $/ 90 \%$ TEOS (B6) xerogel formulations have values of $\theta_{\mathrm{w}}$ of $54^{\circ}$ in comparison with $34^{\circ}$ observed for the B5 coatings. The B6 coatings (B6, B6Se and B6Te) gave reduced settlement of $B$. amphitrite cyprids and Ulva zoospores in the absence of $\mathrm{H}_{2} \mathrm{O}_{2}$ in comparison with the B5 xerogels (B5, B5Se and $\mathrm{B} 5 \mathrm{Te}$ ) and glass controls.

Algae including Ulva produce reactive oxygen species including $\mathrm{H}_{2} \mathrm{O}_{2}$ as by-products of the photosynthetic electron transport system (Ross and van Alstyne 2007). Although $\mathrm{H}_{2} \mathrm{O}_{2}$ is used as an algicide (Drabkova 2007), its efficacy depends on the algal species and the ambient conditions. Green algae appear to be relatively resistant and are reportedly unaffected by concentrations found in surface waters, which is compared with the concentration used in the present experiments. In addition, green algae appear to be relatively resistant to the oxidised halide species (hypohalous acids) that are generated through the action of the catalyst. Concentration $>100 \mathrm{mg}^{-1}$ $(0.001 \mathrm{M})$ of bleach were needed to kill fragments of the green alga Caulerpa (Williams and Schroeder 2004) and, as for $\mathrm{H}_{2} \mathrm{O}_{2}$, efficacy can be reduced by environmental conditions eg the presence of organics in the water.

\section{Conclusions}

Overall, the results indicate that hybrid class II xerogels can be used to sequester catalysts for the activation of $\mathrm{H}_{2} \mathrm{O}_{2}$ in ASW. When the coatings are 'active' in the presence of $\mathrm{H}_{2} \mathrm{O}_{2}$ from a biofilm either on the surface or in the surrounding seawater, reduced settlement of cypris larvae of $B$. amphitrite, larvae of $H$. elegans and zoospores of Ulva have been observed using the Te1 catalyst relative to glass and catalyst-free xerogel controls. The Se1 selenoxide catalyst also gave significantly reduced settlement of cypris larvae of B. amphitrite in ASW in the presence of $20 \mu \mathrm{M} \mathrm{H}_{2} \mathrm{O}_{2}$ when sequestered in the $\mathrm{B} 5 \mathrm{Se}$ coating in comparison with the catalyst-free B5 coating and glass controls. Presumably, the sequestered catalysts facilitate the oxidation of halide salts to positive halogen species with $\mathrm{H}_{2} \mathrm{O}_{2}$. The 'active' surfaces in this study may present localised concentrations of hypohalous acids that discourage settlement of fouling organisms including cypris larvae of $B$. amphitrite, larvae of $H$. elegans and Ulva zoospores.

The various parameters of these coatings have not yet been optimised, but the coatings reported here illustrate the concept of 'active' hybrid xerogels with sequestered catalysts for the activation of $\mathrm{H}_{2} \mathrm{O}_{2}$. The $\mathrm{B} 5$ and $\mathrm{B} 6$ xerogels were selected more for halide permeability rather than for foul-release properties. In these two xerogels, the telluride (Te1) catalyst appeared to be more effective than the selenoxide (Se1) catalyst with statistically significant reductions in settlement observed with the Te1 catalyst with cyprids of $B$. amphitrite, larvae of $H$. elegans and Ulva zoospores in $\mathrm{H}_{2} \mathrm{O}_{2}$-containing ASW relative to catalyst-free xerogel and glass controls. Other hybrid xerogels may have relatively low surface energies, high water contact angles and permeability to both peroxide and halide salts, making them suitable alternatives to the present coatings. The loading level of catalyst has yet to be optimised. Higher loading levels relative to the $0.015 \mathrm{M}$ concentrations used in the sols of this study may provide greatly improved AF properties.

\section{Acknowledgements}

The authors thank the Office of Naval Research for supporting this work through grants to MEC and JAC (award N00014-02-1-0521), MGH (award N00014-05-10579), MRD and FVB (award N0014-02-1-0836) and DEW (award N00014-02-0935). The authors also thank Lenora Brewer for her work on the B. amphitrite data sets.

\section{References}

Abe M, You Y, Detty MR. 2002. 21-Telluraporphyrins. II. Catalysts for bromination reactions with hydrogen peroxide and sodium bromide. Organometallics 21:45464551. 
Avnir D. 1995. Organic chemistry within ceramic matrices: doped sol-gel materials. Acc Chem Res 28:328-341.

Baier RE. 1984. Initial events in microbial film formation. In: Costlow JD, Tipper RC, editors. Marine biodeterioration: an interdisciplinary study. Annapolis (MD): Naval Institute Press. p. 57-62.

Baier RE, Meyer AE. 1992. Surface analysis of foulingresistant marine coatings. Biofouling 6:165-180.

Baier RE, Shaffin EG, Zisman WA. 1968. Adhesion: mechanisms that assist or impede it. Science 162:1360-1368.

Baudrion F, Perichaud A, Vacelet E. 2000. Influence of concentration and structure of quaternary ammonium salts on their antifouling efficiency tested against a community of marine bacteria. Biofouling 14:317-331.

Bennett SM, Tang Y, McMaster D, Bright FV, Detty MR. 2008. Active-site/surface cooperativity in xerogelsequestered selenoxide catalysts for the activation of hydrogen peroxide in an aqueous environment. J Org Chem 73:6849-6852.

Brinker CJ, Scherer GW. 1990. Sol-gel science: the physics and chemistry of sol-gel processing. New York: Academic Press.

Bruckner JJ, Wozniak K, Hardcastle S, Sklyarov A, Seal S, Barr TL. 1999. Cryogenic stabilisation of high vapor pressure samples for surface analysis under ultrahigh vacuum conditions. J Vac Sci Tech A 17:2668-2675.

Callow ME. 1996. Ship-fouling: the problem and methods of control. Biodeterioration Abstr 10:411-421.

Callow ME. 2000. Algal biofilms. In: Evans LV, editor. Biofilms: recent advances in their study and control. Amsterdam: Harwood Academic Publishers. p. 189209.

Callow ME, Callow JA. 2000. Substratum location and zoospore behaviour in the fouling alga Enteromorpha. Biofouling 15:49-56.

Callow ME, Callow JA, Pickett-Heaps JD, Wetherbee R. 1997. Primary adhesion of Enteromorpha (Chlorophyta, Ulvales) propagules: quantitative settlement studies and video microscopy. J Phycol 33:938-947.

Callow ME, Callow JA, Ista LK, Coleman SE, Nolasco AC, Lopez GP. 2000. Use of self-assembled monolayers of different wettabilities to study surface selection and primary adhesion processes of green algal (Enteromorpha) zoospores. Appl Environ Microbiol 66:3249-3254.

Callow ME, Jennings AR, Brennan AB, Seegert CE, Gibson A, Wilson L, Feinberg A, Baney R, Callow JA. 2002. Microtopographic cues for settlement of zoospores of the green fouling alga Enteromorpha. Biofouling 18:237245.

Cavanaugh GM, editor. 1975. Formulae and methods of the marine biological laboratory chemical room. 6th ed. Woods Hole: Marine Biological Laboratory. p. 184.

Chandrasekaran P, Dexter SC. 1993. Mechanism of potential ennoblement on passive metals by seawater biofilms. CORROSION/93. Houston (TX): NACE International. Paper No 493.

Clare AS, Høeg JT. 2008. Balanus amphitrite or Amphiblananus amphitrite? A note on barnacle nomenclature. Biofouling 24:55-57.

Clark CD, De Bruyn WJ, Jakubowski SD, Grant SB. 2008. Hydrogen peroxide production in marine bathing waters: implications for fecal indicator bacteria mortality. Mar Pollut Bull 56:397-401.
Cooper WJ, Zika RG. 1983. Photochemical formation of hydrogen peroxide in surface and ground waters exposed to sunlight. Science 220:771-712.

Cowie PPR, Smith MJ, Hannah F, Cowling MJ, Hodgkeiss T. 2006. The prevention of microfouling and macrofouling on hydrogels impregnated with either Arquad 2C-75 or benzalkonium chloride. Biofouling 22:173185.

Dave BC, Soyez H, Miller JM, Dunn B, Valentine JS, Zink JI. 1995. Synthesis of protein-doped sol-gel $\mathrm{SiO}_{2}$ thin films: evidence for rotational mobility of encapsulated cytochrome c. Chem Mater 7:1431-1434.

Detty MR, Friedman AE, Oseroff A. 1994a. A mechanism for the oxidation of glutathione to glutathione disulfide with organotellurium(IV) and organoselenium(IV) compounds. A step-wise process with implications for photodynamic therapy and other oxidative chemotherapy. J Org Chem 59:8245-8250.

Detty MR, Friedman AE, McMillan M. 1994b. A step-wise mechanism for oxidative addition of bromine to organoselenium(II) and organotellurium(II) compounds. Organometallics 13:3338-3345.

Detty MR, Zhou F, Friedman AE. 1996. Positive halogens from halides and hydrogen peroxide with organotellurium catalysts. J Am Chem Soc 118:313-317.

Dexter SC, Xu K, Luther III GL. 2003. Mn cycling in marine biofilms: effect on the rate of localized corrosion. Biofouling 19(Suppl):139-149.

Drabkova M. 2007. Selective effects of hydrogen peroxide on cyanobacteria photosynthesis. Photosynthetica 45:363369.

Drake MD, Bright FV, Detty MR. 2003. Dendrimeric organochalcogen catalysts for the activation of hydrogen peroxide: origins of the "dendrimer effect" with catalysts terminating in phenylseleno groups. J Am Chem Soc 125:4918-4927.

Eftink MR. 1991. Topics in fluorescence spectroscopy. Vol. 2. New York: Plenum Press.

Finlay JA, Callow ME, Schultz MP, Swain GW, Callow JA. 2002. Adhesion strength of settled spores of the green alga Enteromorpha. Biofouling 18:251-256.

Francavilla C, Bright FV, Detty MR. 2000. Dendrimeric catalysts for the activation of hydrogen peroxide. Increasing activity per catalytic phenylseleno group in successive generations. Org Lett 1:1043-1046.

Francavilla C, Drake MD, Bright FV, Detty MR. 2001. Dendrimeric organochalcogen catalysts for the activation of hydrogen peroxide. Improved catalytic activity through statistical effects and cooperativity in successive generations. J Am Chem Soc 123:57-67.

Genzer J, Efimenko K. 2006. Recent developments in superhydrophobic surfaces and their relevance to marine fouling: a review. Biofouling 22:339-360.

Gerhart DJ, Rittschof D, Hooper IR, Eisenman K, Meyer AE, Baier RE, Young C. 1992. Rapid and inexpensive quantification of the combined polar components of surface wettability: application to biofouling. Biofouling $5: 251-259$.

Goodman MA, Detty MR. 2004. Selenoxides as catalysts for the activation of hydrogen peroxide. Bromination of organic substrates with sodium bromide and hydrogen peroxide. Organometallics 23:3016-3020.

Hayden HS, Blomster J, Maggs CA, Silva PC, Stanhope MJ, Waaland RJ. 2003. Linneaeus was right all along: Ulva and Enteromorpha are not distinct genera. Eur J Phycol 38:277-294. 
Higgs D, Nelen MI, Detty MR. 2001. Iodination of organic substrates with halide salts and $\mathrm{H}_{2} \mathrm{O}_{2}$ using an organotelluride catalyst. Org Lett 3:349-352.

Ingersoll CM, Bright FV. 1997. Using sol-gel-based platforms for chemical sensors. CHEMTECH 27:26-35.

Jordan JD, Dunbar RA, Hook DJ, Zhuang H, Gardella JA, Colón LA, Bright FV. 1998. Production, characterization, and utilization of aerosol-deposited sol-gel-derived films. Chem Mater 10:1041-1051.

Kavanagh CJ, Quinn RD, Swain GE. 2005. Observations of barnacle detachment using high-speed video. J Adhesion 81:843-850.

Lakowicz JR. 1999. Principles of fluorescence spectroscopy. 2nd ed. New York: Kluwer Academic/Plenum Publishers.

Le Bozec N, Compere C, L'Her M, Laouenan A, Costa D, Marcus P. 2001. Influence of stainless steel surface treatment on the oxygen reduction reaction in seawater. Corrosion Sci 43:765-786.

Otani M, Oumi T, Uwai S, Hanyuda T, Prabowo TRE, Yamaguchi T, Kawai H. 2007. Occurrence and diversity of barnacles on international ships visiting Osaka Bay, Japan, and the risk of introduction. Biofouling 23:277-286.

Pandey S, Baker GA, Kane MA, Bonzagni NJ, Bright FV. 2000. On the microenvironments surrounding dansyl sequestered within class I and II xerogels. Chem Mater 12:3547-3551.

Pettengill JB, Wendt DE, Schug MD, Hadfield MG. 2007. Biofouling likely serves as a major mode of dispersal for the polychaete tubeworm Hydroides elegans as inferred from microsatellite loci. Biofouling 23:161-169.

Rittschof D, Costlow D. 1989. Bryozoan and barnacle settlement in relation to initial surface wettability: a comparison of laboratory and field studies August 1987. In: Ros JD, editor. Topics in marine biology. Proceedings of the 22nd European Marine Biology Symposium; Barcelona, Spain: Instituto de Ciencias del MarAugust 1987. p. 411-426.

Rittschof D, Forward, RB Jr, Cannon G, Welch JM, McClary, Jr MM, Holm ER, Clare AS, Conova S, McKelvey LM, Bryan P, et al. 1998. Cues and context: larval responses to physical and chemical cues. Biofouling 12:31-44.

Ross C, Van Alstyne KL. 2007. Intraspecific variation in stress-induced hydrogen peroxide scavenging by the ulvoid macroalga Ulva lactuca. J Phycol 43:466-474.
Schultz MP. 2007. Effects of coating roughness and biofouling on ship resistance and powering. Biofouling 23: 331-341.

Tang Y, Tehan EC, Tao ZY, Bright FV. 2003. Sol-gelderived sensor materials that yield linear calibration plots, high sensitivity, and long-term stability. Anal Chem 75:2407-2413.

Tang Y, Finlay JA, Kowalke GL, Meyer AE, Bright FV, Callow ME, Callow JA, Wendt DE, Detty MR. 2005. Hybrid xerogel films as novel coatings for antifouling and fouling release. Biofouling 21:59-71.

Tao Z, Tehan EC, Tang Y, Bright FV. 2006. Highly stable sensors with tunable sensitivities based on class II xerogels. Anal Chem 78:1939-1945.

Townsin RL. 2003. The ship hull fouling penalty. Biofouling 19(Suppl):9-15.

Wendt DE, Kowalke GL, Kim J, Singer IL. 2006. Factors that influence elastomeric coating performance: the effect of coating thickness on basal plate morphology, growth and critical removal stress of the barnacle Balanus amphitrite. Biofouling 22:1-9.

Willey JD, Paerl HW, Go M. 1999. Impact of rainwater hydrogen peroxide on chlorophyll $a$ content of surface Gulf Stream seawater off North Carolina, USA. Mar Ecol Prog Ser 178:145-150.

Williams SL, Schroeder SL. 2004. Eradication of the invasive seaweed Caulerpa taxifolia by chlorine bleach. Mar Ecol Prog Ser 272:69-76.

Yebra DM, Kiil S, Dam-Johansen K. 2004. Antifouling technology - past, present and future steps towards efficient and environmentally friendly antifouling coatings. Prog Org Coat 50:75-104.

You Y, Ahsan K, Detty MR. 2003. Mechanistic studies of the tellurium(II)/tellurium(IV) redox cycle in thiol peroxidase-like reactions of diorganotellurides in methanol. J Am Chem Soc 125:4918-4927.

Yuan J, Shiller AM. 2000. The variation of hydrogen peroxide in rain water over the South and Central Atlantic Ocean. Atm Environ 34:3973-3980.

Yuan J, Shiller AM. 2001. The distribution of hydrogen peroxide in the southern and central Atlantic Ocean. Deep Sea Res II 48:2947-2970. 